\title{
Effects of different fertilization practices on the growth, yield and dry matter content of carrot
}

\author{
AINO-MAIJA EVERS \\ Kemira Oy, Espoo Research Centre, Luoteisrinne 2 \\ SF-02270 Espoo, Finland
}

\begin{abstract}
The effects of different fertilization practices on the carrot root and shoot dry weights, yield, dry matter contents and root/shoot ratio were studied in field experiments. Unirrigated and irrigated placement and broadcast fertilization, fertirrigations without basic fertilization, fertirrigations with basic fertilization, and PK placement with $\mathrm{N}$ fertirrigations were compared. In addition, split application was compared to single application of nutrients. The soil nutrient levels were studied by soil analysis. The carrot root and shoot samples were collected three times during the growing period. Cv. Nantes Duke Notabene $\mathbf{3 7 0}$ was grown.

The carrot shoots reached their maximum weight already by three months, whereas roots grew slowly during the first two months but grew considerably during both the third and fourth month. The root and shoot dry weights were positively correlated at all sampling dates in both years $\left(: \geqq 0.77^{* * *}\right)$. The big photosynthetizing apparatus caused the production of high root yield. The placement fertilization of granular NPK fertilizer increased the yield as compared to broadcast of granular NPK fertilizer $\left(\mathrm{p}=0.009^{* *}\right)$. The yield was also increased by the placement of $\mathrm{P}$ and $\mathrm{K}$ as compared to treatments without placement fertilization of $\mathrm{P}$ and $\mathrm{K}$ $\left(p=0.03^{*}\right)$. There was no difference in yields between single application and split application. Irrigation decreased the yield in $1985\left(\mathrm{p}=0.03^{*}\right)$. In 1986 the yield was significantly higher than in $1985\left(\mathrm{p}=0.000^{* * *}\right)$.

At harvest the fertilization did not affect the dry matter content of carrot roots when compared with unfertilized treatments. The difference in dry matter content was greater between years $\left(p=0.000^{* * *}\right)$ than between fertilization practices $\left(p=0.05^{*}\right)$. The treatment PK placement with $\mathrm{N}$ fertirrigations yielded carrots with a higher dry matter content than did the NPK fertirrigation treatments. Besides the fertilization experiment samples from two organically cultivated fields were collected to obtain data concerning organically cultivated carrots and soils.
\end{abstract}

Key words: fertilization practices, carrot, quality, fresh weight, dry weight, yield, dry matter content, root/shoot ratio

\section{Introduction}

Crop yield depends on total production of biomass and the distribution of dry matter between yielding and non-yielding parts of the plant (Hole et al. 1983). In carrots (Daucus carota L.), the leaves constitute the source of photosynthate production, and the roots form 
the main sink where photosynthates are used and stored.

Scant research data are available about whether high root yield is correlated with big foliage or about the optimal root/shoot ratio during different growing periods in carrot production. From the economic point of view, it is important to have a high root yield at harvest, and it can be assumed that big photosynthetizing apparatus during the growing period leads to high production of photosynthates for the sink. Dragland (1978) reported that the fertilizer level which gave the highest root yield had also the biggest foliage at harvest. He did not measure the root/shoot ratio during the growing season. TANAKA (1980) reported that the timing of nitrogen application to rice has the effect of manipulating the source-sink relationship.

Broadcast fertilization is the most common fertilization practice in carrot production in Finland. The split application is not used. The nutrient amounts used are 80-
$140 \mathrm{~kg} \mathrm{~N} / \mathrm{ha}, 30-70 \mathrm{~kg} \mathrm{P} / \mathrm{ha}$ and $60-200 \mathrm{~kg}$ $\mathrm{K} / \mathrm{ha}$. In corn production in Finland, placement fertilization has given very good results (Aura 1967, Kaila \& Elonen 1970, Esala \& LARPES 1986 a, b).

The aim of the present study was to determine whether the root and shoot dry weights, yield, dry matter contents and the root/shoot ratio can be affected by developing the methods of fertilizer application. Placement fertilization, broadcast fertilization, fertirrigation, and their combinations were compared. The split application was also compared to single application of nutrients.

\section{Materials and methods}

The field experiments were carried out on the Kotkaniemi Experimental Farm of Kemira Ltd. in Vihti $\left(60^{\circ} 22^{\prime} \mathrm{N}, 24^{\circ} 22^{\prime} \mathrm{E}\right)$ during the growing seasons of 1985 and 1986 . The trials were set up according to the method of completely randomized blocks, four blocks

Table 1. The fertilization treatments.

\begin{tabular}{|c|c|c|c|c|c|c|c|}
\hline \multirow{2}{*}{\multicolumn{2}{|c|}{ Treatment }} & \multirow[t]{2}{*}{ Code } & \multirow[t]{2}{*}{$\begin{array}{l}\text { Number and time of } \\
\text { fertilizer applications }\end{array}$} & \multicolumn{3}{|c|}{$\begin{array}{l}\text { Macro nutrient } \\
\text { amounts in } 1986^{3} \\
\mathrm{~kg} / \mathrm{ha}\end{array}$} & \multirow{2}{*}{$\begin{array}{l}\text { Irrigation water } \\
\text { amounts in } \\
1985 \text { and } 1986 \\
\text { mm }\end{array}$} \\
\hline & & & & $\mathrm{N}$ & $\mathrm{P}$ & K & \\
\hline No & $\begin{array}{l}\text { fertilization } \\
\text { No irrigation } \\
\text { Irrigation }\end{array}$ & $\begin{array}{l}\mathrm{P} 0 \\
\mathrm{P} 1\end{array}$ & $\begin{array}{l}0 \\
0\end{array}$ & $\begin{array}{l}0 \\
0\end{array}$ & $\begin{array}{l}0 \\
0\end{array}$ & $\begin{array}{l}0 \\
0\end{array}$ & $\begin{array}{l}0 \\
3 \times 10\end{array}$ \\
\hline NPK & $\begin{array}{l}\text { placement } \\
\text { No irrigation } \\
\text { Irrigation }\end{array}$ & $\begin{array}{l}\text { P2 } \\
\text { P3 }\end{array}$ & $\begin{array}{l}1 \text { before sowing } \\
1 \text { before sowing }\end{array}$ & $\begin{array}{l}80 \\
80\end{array}$ & $\begin{array}{l}35 \\
35\end{array}$ & $\begin{array}{l}133 \\
133\end{array}$ & $\begin{array}{l}0 \\
3 \times 10\end{array}$ \\
\hline NPK & $\begin{array}{l}\text { broadcast } \\
\text { No irrigation } \\
\text { Irrigation }\end{array}$ & $\begin{array}{l}\text { P4 } \\
\text { P5 }\end{array}$ & $\begin{array}{l}1 \text { before sowing } \\
1 \text { before sowing }\end{array}$ & $\begin{array}{l}80 \\
80\end{array}$ & $\begin{array}{l}35 \\
35\end{array}$ & $\begin{array}{l}133 \\
133\end{array}$ & $\begin{array}{l}0 \\
3 \times 10\end{array}$ \\
\hline NPK & $\begin{array}{l}\text { fertirrigation } \\
\text { No basic } \\
1 / 2 \text { NPK basic } 1\end{array}$ & $\begin{array}{l}\text { P6 } \\
\text { P7 }\end{array}$ & $\begin{array}{l}3 \text { during season } \\
1 \text { before sowing and } \\
3 \text { during season }\end{array}$ & $\begin{array}{l}80 \\
80\end{array}$ & $\begin{array}{l}29 \\
32\end{array}$ & $\begin{array}{l}160 \\
142\end{array}$ & $\begin{array}{l}3 \times 10 \\
3 \times 10\end{array}$ \\
\hline PK & $\begin{array}{l}\text { placement }^{2} \\
3 \mathrm{~N} \text {-fertirrigation }\end{array}$ & P8 & $\begin{array}{l}1 \text { before sowing and } \\
3 \text { during season }\end{array}$ & 81 & 56 & 133 & $3 \times 10$ \\
\hline & $4 \mathrm{~N}$-fertirrigation & P9 & $\begin{array}{l}1 \text { before sowing and } \\
4 \text { during season }\end{array}$ & 155 & 56 & 133 & $3 \times 10$ \\
\hline
\end{tabular}

\footnotetext{
1 Half of the nutrients were given in basic placement fertilization and half in NPK fertirrigations.

2 Phosphorus and potassium were given in basic placement fertilization and nitrogen in fertirrigations.

${ }^{3}$ The nutrient amounts were $33 \%$ higher in 1985 than in 1986.
} 
(I-IV), ten treatments (P0-P9, Table 1) and plots of $25 \mathrm{~m}^{2}$ ( 55 row meters in each). The data were studied by contrast analysis (P0-P9) and by analysis of variance as a factorial experiment (P0-P5), where the fertilization levels were 1) no fertilization, 2) placement fertilization, 3) broadcast fertilization. The irrigation levels were 1) no irrigation, 2) irrigation (STeel \& Torrie 1980).

Simultaneously with the fertilization experiment, samples from two organically cultivated fields were collected in 1986. These were grown with the same seed material, but the geographical position, climate and soil characteristics were different. The aim of this sampling was to obtain some data concerning organically cultivated carrots and soils.

\section{Fertilization}

In placement fertilization treatments (Table 1) the granular NPK fertilizer (10-4-17 with microelements) was placed $8 \mathrm{~cm}$ deep in the soil, and the fertilizer rows were marked. The seeds were sown with a MiniNibex sowing machine $1 \mathrm{~cm}$ deep and $3 \mathrm{~cm}$ beside the fertilizer row. In broadcast treatments, the granular NPK-fertilizer (10-4-17 with micronutrients) was spread on the soil surface and harrowed with a rotary cultivator. In the
NPK fertirrigation treatments the watersoluble NPK fertilizer (10-3.6-20) was dissolved in water and spread with a self-made boom. The same boom was used in irrigation. In NPK-fertirrigation treatment with basic fertilization, half of the nutrients was applied with granular NPK fertilizer (10-4-17 with microelements) by the placement method, and half of nutrients with soluble NPK fertilizer (10-3.6-20) in three applications. In Nfertirrigation treatments, the basic PK-fertilization was done with granular PK-fertilizer (0-7-17 with microelements) by placement method. The nitrogen fertilizer (1985 calcium nitrate, 1986 urea) was dissolved in water and spread with the boom three or four times during the growing season. All fertilizer percentages are expressed as pure elements.

The basic fertilization was done on 4th June, 1985 and 6th June, 1986. The fertirrigations and irrigations were done on 14th June, 5th July and 19th July, 1985 and on 26th June, 10th July and 24th July, 1986.

In 1986 the amounts of nutrients in the treatments were $33 \%$ less than in 1985 (Table 1). All fertilized treatments contained the same amounts of micronutrients, $1.2 \mathrm{~kg} \mathrm{~B} / \mathrm{ha}$, $0.8 \mathrm{~kg} \mathrm{Fe} / \mathrm{ha}, 0.8 \mathrm{~kg} \mathrm{Cu} / \mathrm{ha}, 0.8 \mathrm{~kg} \mathrm{Zn} / \mathrm{ha}$, $5.6 \mathrm{~kg} \mathrm{Mn} / \mathrm{ha}, 0.08 \mathrm{~kg} \mathrm{Mo} / \mathrm{ha}$ and $0.013 \mathrm{~kg}$ $\mathrm{Se} / \mathrm{ha}$. The treatment NPK-fertirrigation

Table 2. The nutrient contents of composts used at the organically cultivated locations as well as the amounts of nutrients given in compost fertilization.

\begin{tabular}{|c|c|c|c|c|}
\hline & \multicolumn{2}{|c|}{$\begin{array}{c}\text { The nutrient contents } \\
\text { of composts } \\
\% \text { in dry matter }\end{array}$} & \multicolumn{2}{|c|}{$\begin{array}{l}\text { The amount of nutrients } \\
\text { given in fertilization } \\
\mathrm{kg} / \mathrm{ha}\end{array}$} \\
\hline & Location 1 & Location 2 & Location 1 & Location 2 \\
\hline Water-soluble $\mathrm{N}$ & 0.18 & 0.07 & 113 & 47 \\
\hline Total N & 0.73 & 0.63 & 450 & 424 \\
\hline Total P & 0.45 & 0.39 & 275 & 262 \\
\hline K & 0.53 & 0.44 & 325 & 296 \\
\hline $\mathrm{Mg}$ & 0.41 & 0.41 & 250 & 276 \\
\hline S & 0.13 & 0.12 & 77 & 81 \\
\hline B & 0.002 & 0.002 & 1.5 & 1.3 \\
\hline $\mathrm{Fe}$ & 1.01 & 1.05 & 619 & 706 \\
\hline $\mathrm{Cu}$ & 0.002 & 0.002 & 1.0 & 1.3 \\
\hline $\mathrm{Zn}$ & 0.008 & 0.01 & 4.8 & 6.7 \\
\hline $\mathrm{Mn}$ & 0.03 & 0.02 & 18.4 & 13.5 \\
\hline Mo & 0.00009 & 0.0001 & 0.055 & 0.067 \\
\hline
\end{tabular}


Table 3. Weather conditions at Vihti in 1985 and 1986 and the 30-year average.

\begin{tabular}{|c|c|c|c|c|c|c|c|c|c|}
\hline & \multicolumn{3}{|c|}{$\begin{array}{c}\text { Mean day temperature } \\
{ }^{\circ} \mathrm{C}\end{array}$} & \multicolumn{3}{|c|}{$\begin{array}{l}\text { Precipitation } \\
\text { mm }\end{array}$} & \multicolumn{3}{|c|}{$\underset{\mathrm{h}}{*}$ Sunshine hours } \\
\hline & 1985 & 1986 & $1931-60$ & 1985 & 1986 & $1931-60$ & 1985 & 1986 & $1959-84$ \\
\hline May & 9.0 & 10.8 & 9.0 & 40 & 51 & 39 & 263 & 267 & 268 \\
\hline June & 13.2 & 16.3 & 14.2 & 52 & 28 & 46 & 250 & 326 & 282 \\
\hline July & 15.4 & 16.3 & 16.8 & 72 & 103 & 73 & 236 & 281 & 254 \\
\hline August & 15.8 & 13.2 & 14.9 & 79 & 138 & 77 & 199 & 154 & 212 \\
\hline September & 8.7 & 6.4 & 9.9 & 75 & 88 & 66 & 145 & 135 & 127 \\
\hline October & 6.8 & 5.5 & 4.7 & 29 & 74 & 65 & 108 & 87 & 71 \\
\hline Total & & & & 347 & 482 & 366 & 1,201 & 1,250 & 1,214 \\
\hline
\end{tabular}

* Helsinki-Vantaa airport

without basic contained no Fe at all, whereas the treatment NPK-fertirrigation with $1 / 2$ basic contained $0.4 \mathrm{~kg} \mathrm{Fe} / \mathrm{ha}$. During winter 1985 the experimental field was limed with dolomite lime, $5,000 \mathrm{~kg} / \mathrm{ha}$.'

The biologically cultivated fields were fertilized with compost, $1,250 \mathrm{~kg} / 100 \mathrm{~m}^{2}$ (Table 2).

\section{Growing technique and climate}

The carrots were grown according to the normal growing practise used in Finland. Seeds of cv. Nantes Duke Notabene 370 were coated with a mixture of lindan $(75 \%)$ and tiram (10\%), using $120 \mathrm{~g}$ pesticide/ $\mathrm{kg}$ seeds. The seeds were sown on 8th June, 1985 and 9th June, 1986. The organically cultivated carrots were sown on 14th May, 1986 at location one and 21st May, 1986 at location two. The plants were thinned for 30 plants $/ \mathrm{m}$. Weeds were sprayed with promethryn twice per year. Sypermetrin was used for protection against Trioza apicalis $\mathrm{F}$. The information on climate is given in Table 3 .

\section{Carrot samples}

The total growing time was four months. The first sampling date was 2.5 months after sowing in 1985, 2 months in 1986. The second sampling date was 3 months after sowing. The third sampling date was at harvest, four months after sowing. Each time, 20 consecutive plants per plot were collected from the middle of the plantation. For dry weight the shoots and roots were dried at $60^{\circ} \mathrm{C}$ for 48 hours. The dry matter content is expressed as the percentage of dry weight in fresh weight.

\section{Soil samples}

Soil samples were collected across the carrot row from a soil layer $15 \mathrm{~cm}$ deep. In all, eight partial samples per plot were gathered at equal distances across the plot. Soil samples were taken two days before sowing and 6, 27, 41, 54, 76, 96 and 116 days after sowing in 1985 . In 1986 the soil samples were taken one day before sowing and 18, 31, 46, 65 and 117 day after sowing.

Soil samples were analysed in a commercial laboratory, Viljavuuspalvelu $\mathrm{Oy}$, located in Helsinki. $\mathrm{NO}_{3}-\mathrm{N}$ was extracted with water $\left(+20^{\circ} \mathrm{C}\right)$ and determined by the ionspecific electrode method (modification of BREMNER et al. 1968). $\mathrm{NH}_{4}-\mathrm{N}$ was extracted with 0,1 $\mathrm{M} \mathrm{K}_{2} \mathrm{SO}_{4}$ and determined by the Kjeldahl procedure. $\mathrm{P}, \mathrm{K}, \mathrm{Ca}$ and $\mathrm{Mg}$ were extracted with ammonium acetate, $\mathrm{pH}$ 4.65. $\mathrm{P}$ was determined by spectrophotometry, using ammoniummolybdate as the colour reagent; $\mathrm{Mg}$ was determined by AAS (Atomic absorption spectrophotometer), $\mathrm{K}$ and $\mathrm{Ca}$ by a flame photometer (VUORINEN \& MĀKITIE 1955). B was extracted with boiling water $\left(+100^{\circ} \mathrm{C}\right)$ and determined by an ICP-spectrometer (BERger \& Truog 1944). S was extracted with $0.01 \mathrm{M} \mathrm{CaCl}_{2}$ and determined gravimetrically with barium sulphate (SALONEN et al. 1965). 
Table 4. Chemical characteristics of experimental blocks (1985), treatments (1986) and biologically cultivated fields (1986) in the spring before fertilization.

\begin{tabular}{|c|c|c|c|c|c|c|c|c|c|c|c|c|c|c|c|}
\hline 1985 & $\mathrm{pH}$ & jl & $\mathrm{NO}_{3}-\mathrm{N}$ & $\mathrm{NH}_{4}-\mathrm{N}$ & $\mathrm{P}$ & K & $\mathrm{Ca}$ & $\mathrm{Mg}$ & $\mathrm{S}$ & B & $\mathrm{Fe}^{*}$ & $\mathrm{Mn}^{*}$ & $\mathrm{Cu}^{*}$ & $\mathrm{Zn}^{*}$ & $\mathrm{Mo}^{*}$ \\
\hline I & 5.6 & 0.6 & $<10$ & 3.9 & 7 & 115 & 1675 & 240 & 12.4 & 0.7 & 11.0 & 7.9 & 7.8 & 29.3 & 0.51 \\
\hline II & 5.7 & 0.3 & $<10$ & 0.1 & 11 & 95 & 1000 & 75 & 7.0 & 0.5 & 4.7 & 9.4 & 4.4 & 14.7 & 0.53 \\
\hline III & 5.8 & 0.5 & $<10$ & 2.5 & 9 & 110 & 1625 & 140 & 4.6 & 0.7 & 9.0 & 6.8 & 8.6 & 25.0 & 0.64 \\
\hline IV & 5.7 & 0.6 & $<10$ & 0.1 & 10 & 95 & 1050 & 65 & 8.5 & 0.6 & 3.1 & 8.8 & 7.0 & 13.7 & 0.68 \\
\hline \multicolumn{16}{|l|}{1986} \\
\hline $\mathrm{P}^{1}$ & 6.2 & 1.0 & 1.0 & 1.3 & 10.6 & 110 & 2356 & 135 & 4.4 & 0.6 & 450 & 12.2 & 3.9 & 3.6 & 0.09 \\
\hline P1 & 6.4 & 1.3 & 0.9 & 0.2 & 9.4 & 110 & 3050 & 119 & 7.8 & 0.6 & 430 & 8.8 & 3.9 & 6.6 & 0.07 \\
\hline P2 & 6.3 & 0.9 & 0.9 & 0.4 & 10.6 & 143 & 2475 & 144 & 9.9 & 0.8 & 520 & 11.8 & 4.0 & 3.3 & 0.09 \\
\hline P3 & 6.2 & 0.8 & 0.6 & 0.4 & 11.3 & 135 & 2194 & 108 & 8.9 & 0.8 & 440 & 12.0 & 4.0 & 3.6 & 0.09 \\
\hline P4 & 6.3 & 0.9 & 1.4 & 2.1 & 11.3 & 115 & 2625 & 119 & 4.8 & 0.6 & 410 & 11.0 & 4.3 & 4.6 & 0.09 \\
\hline P5 & 6.3 & 1.0 & 2.4 & 2.1 & 10.8 & 123 & 2794 & 155 & 3.3 & 0.7 & 480 & 9.2 & 4.1 & 4.1 & 0.08 \\
\hline P6 & 6.2 & 0.9 & 0.8 & 1.6 & 11.7 & 138 & 2613 & 154 & 11.0 & 0.8 & 480 & 12.8 & 4.8 & 4.0 & 0.12 \\
\hline P7 & 6.4 & 0.9 & 0.8 & 2.6 & 10.6 & 126 & 3175 & 151 & 7.7 & 0.7 & 600 & 12.0 & 4.8 & 3.6 & 0.12 \\
\hline P8 & 6.4 & 0.9 & 0.9 & 4.6 & 14.8 & 140 & 2513 & 113 & 12.0 & 0.8 & 420 & 11.5 & 4.1 & 5.1 & 0.11 \\
\hline P9 & 6.3 & 1.0 & 0.9 & 7.8 & 12.1 & 136 & 2575 & 109 & 7.7 & 0.8 & 410 & 11.9 & 4.2 & 3.8 & 0.12 \\
\hline $\mathrm{L}^{2}$ & 6.2 & 0.4 & 11 & 2.7 & 20 & 88 & 725 & 80 & 3.2 & 0.3 & 210 & 39 & 2.8 & 9.2 & 0.13 \\
\hline L2 & 7.2 & 0.9 & 12 & 4.6 & 126 & 218 & 2475 & 296 & 1.9 & 0.7 & 360 & 19 & 5.6 & 23.0 & 0.08 \\
\hline
\end{tabular}

* Different determinations in 1985 and 1986.

I See treatments in Table 1.

2 Organically cultivated fields.

In $1985, \mathrm{Fe}, \mathrm{Cu}, \mathrm{Zn}, \mathrm{Mn}$ and $\mathrm{Mo}$ were extracted with ammonium acetate $(\mathrm{pH} 4.65)$. In 1986 these elements were extracted with ammonium acetate-EDTA (pH 4.65, $0.02 \mathrm{M}$ EDTA). $\mathrm{Fe}, \mathrm{Cu}, \mathrm{Zn}$ and $\mathrm{Mn}$ were determined by flame AAS and Mo by flameless AAS (LAKANEN \& ERVIö 1971).

The first sampling was done before the fertilization application on 4th June 1985 by blocks and 6th June 1986 by treatments, because the same plots were used each year (Table 4). Table 4 also presents the results for the biologically cultivated fields (location 1 at Varkaus and location 2 at Rantasalmi). The soil in the fertilizer trial was fine sand (15-30 \% clay), with a humus content of $12-20 \%$. The soil in the organically cultivated fields was fine sand moraine, with a humus content of $3-6 \%$ in one location and of $12-20 \%$ in the other location.

\section{Results}

\section{Growing rhythm}

On average, the carrot shoots grew faster in 1986 that in 1985 (Fig. 1). By the middle of the growing season, the carrot shoots reached $40 \%$ of their final shoot fresh weight in 1985, $68 \%$ in 1986. By the third quarter of the growing season, the shoots reached $95 \%$ and $113 \%$ of their final fresh weight but only $75 \%$ and $95 \%$ of their final dry weight in 1985 and 1986, respectively. In both years the final shoot yield was very similar.

Carrot roots developed slowly. By the middle of the growing season, the root fresh weight reached only $17 \%$ (1985) and $26 \%$ (1986) of the final root fresh weight. The corresponding figures on the second sampling date were $59 \%$ and $72 \%$. Thus the carrot root weight increased considerably during the last month of the growing period. The result was similar when calculated for dry matter.

In 1985, the mean weights of a single carrot root were $15.4 \mathrm{~g}, 53 \mathrm{~g}$ and $89 \mathrm{~g}$ on the consecutive sampling dates. The corresponding weights in 1986 were $27.2 \mathrm{~g}, 77 \mathrm{~g}$ and $106 \mathrm{~g}$.

\section{Root dry weight}

The difference in the dry weights of roots between treatments increased as the growing 


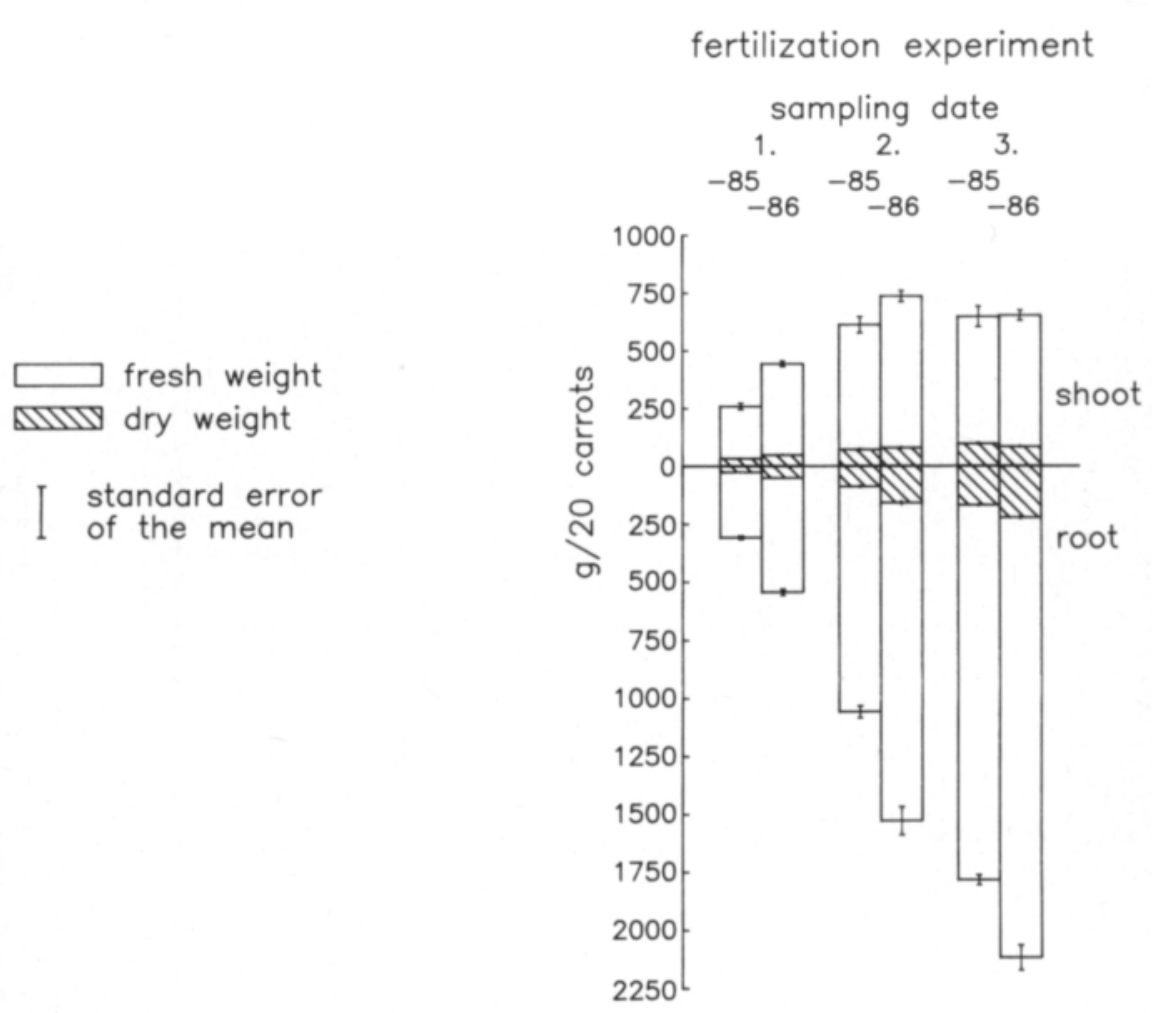

organically cultivated fields

sampling date

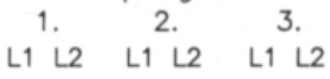

${ }^{1000}[$

$\square$ fresh weight

dry weight

standard error
of the mean

L1 location one

L2 location two

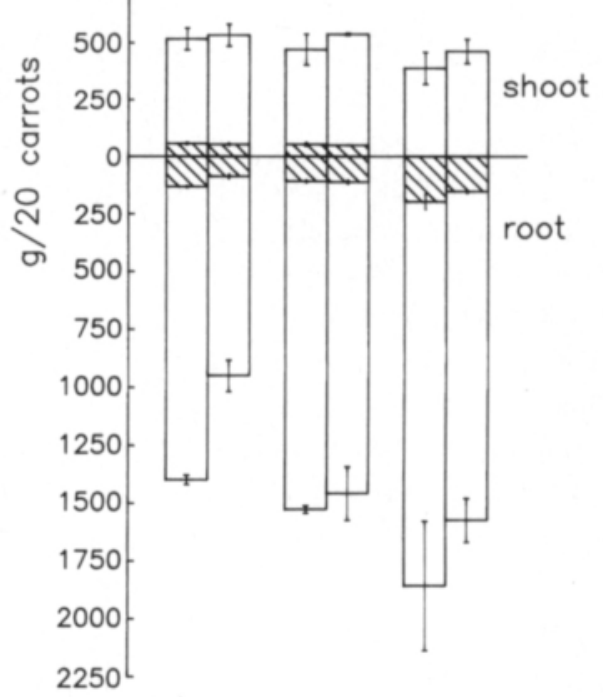

Fig. 1. The development of fresh and dry weights of roots and shoots on three sampling dates in the fertilization experiment and in the organically cultivated locations. 

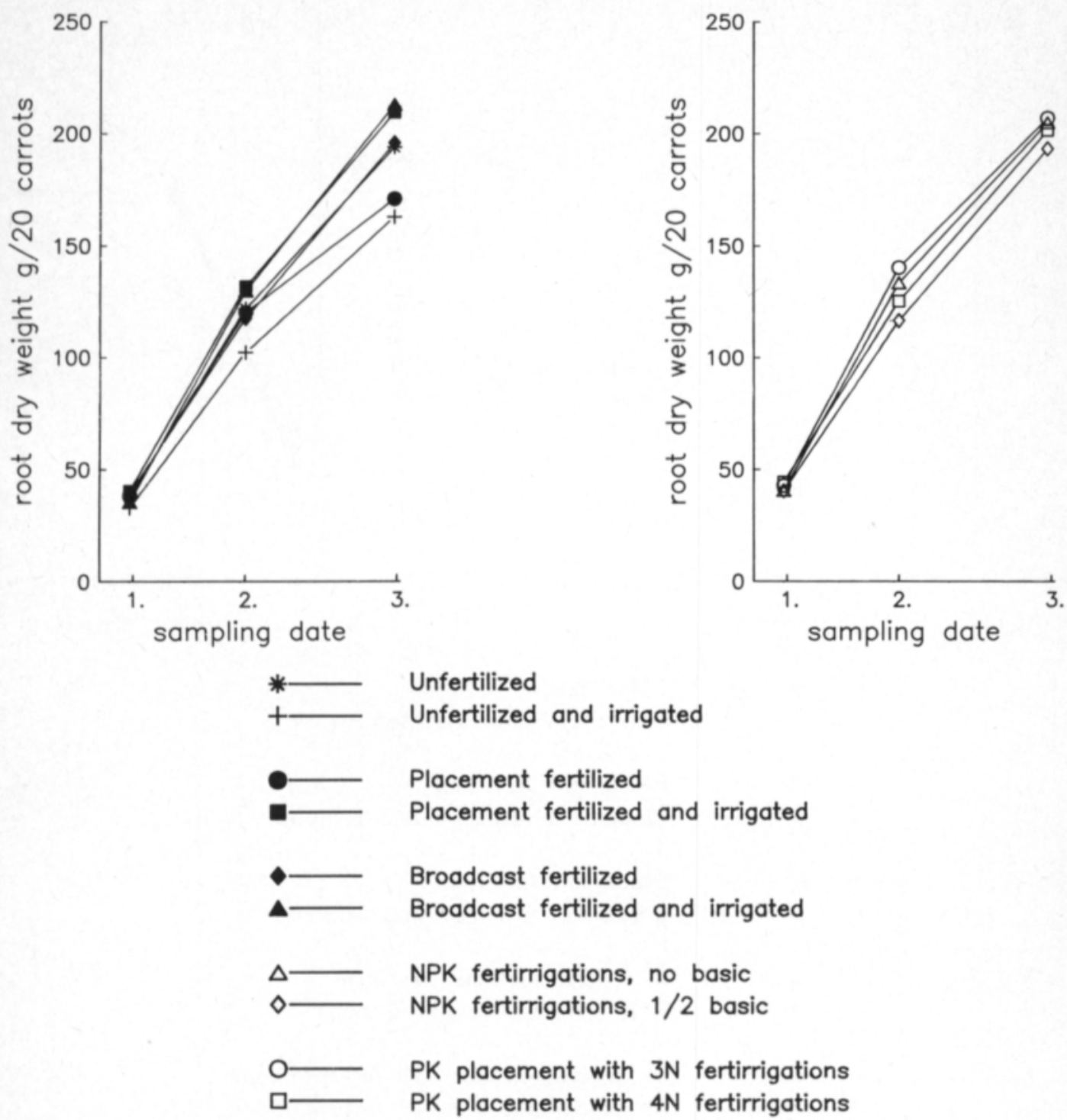

Fig. 2. The effect of different fertilization practices on the development of the dry weights of roots.

season proceeded (Fig. 2). There was no notable difference on the first sampling date, two months after sowing. Three months after sowing, on the second sampling date, the highest dry weight of roots was obtained with the $\mathrm{PK}$ placement with $3 \mathrm{~N}$ fertirrigations treatment. The difference between the highest and the lowest root dry weights in fertilized treatments was $23.7 \mathrm{~g} / 20$ carrots, which equals a calculated value of $711 \mathrm{~kg}$ dry matter/ha (Fig. 2).
At harvest the best fertilization practices, according to the dry weight of carrot roots, were irrigated broadcast, irrigated placement and $\mathrm{PK}$ placement with $3 \mathrm{~N}$ fertirrigations. The difference between the fertilization treatment yielding the highest dry weights of roots and the fertilization treatment yielding the lowest dry weights of roots was $42.1 \mathrm{~g} / 20$ carrots, which equals a calculated difference of 1,263 $\mathrm{kg}$ dry matter/ha (Fig. 2). 

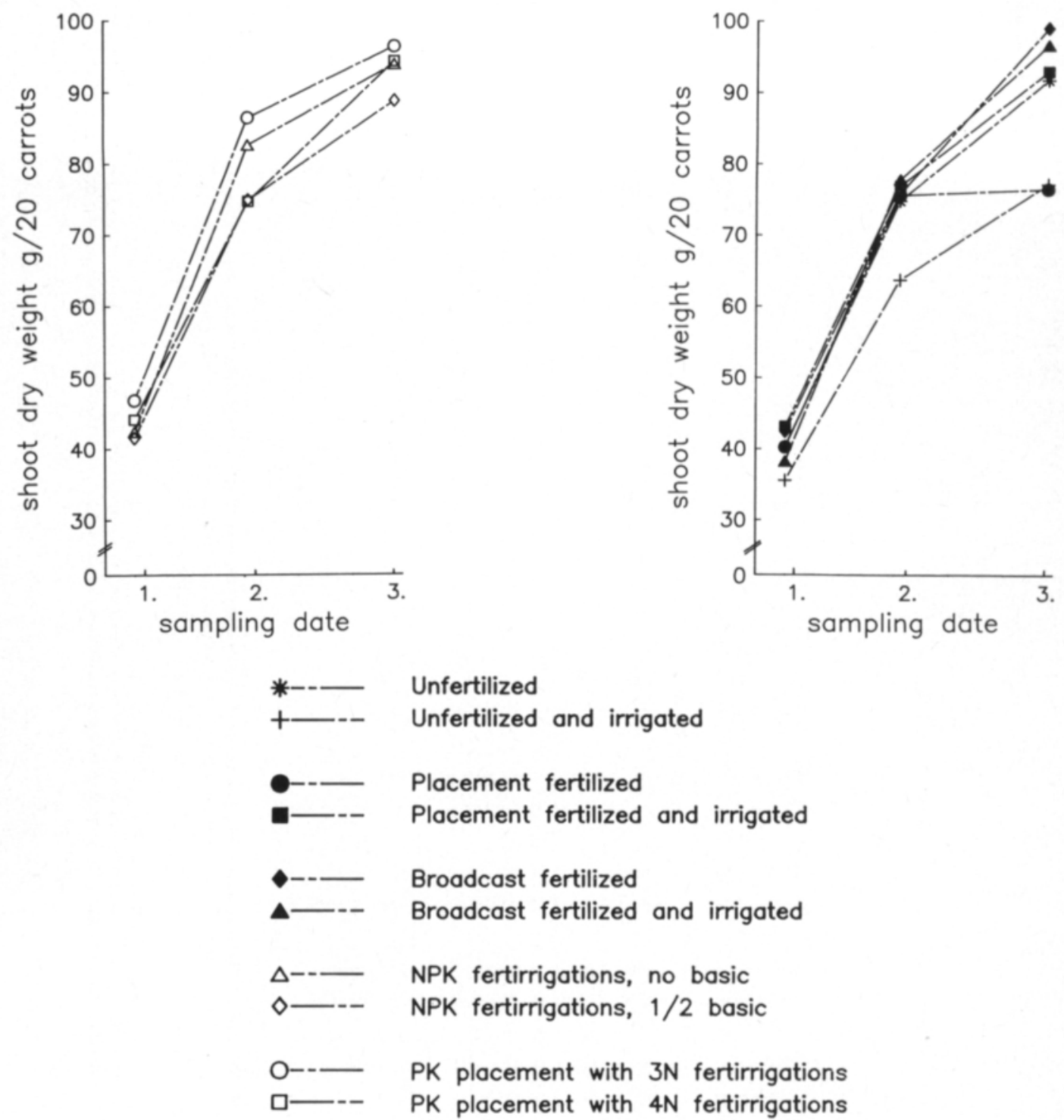

Fig. 3. The effect of different fertilization practices on the development of the dry weights of shoots.

\section{Shoot dry weight}

The shoot dry weight varied already on the first sampling date (Fig. 3). In fertilized treatments the difference between the highest and the lowest value was about similar on the first, second and third sampling dates, being 8.6, 11.7 and $10.4 \mathrm{~g} / 20$ carrots, respectively (at harvest the unirrigated placement fertilized treatment was omitted).

The root and shoot dry weights were posi- tively correlated on all sampling dates and in the two years as follows:

$\begin{array}{llll} & \text { KA1 } & \text { KA2 } & \text { KA3 } \\ 1985 & \mathrm{r}=0.86^{* * *} & \mathrm{r}=0.77^{* * *} & \mathrm{r}=0.79^{* * *} \\ 1986 & \mathrm{r}=0.77^{* * *} & \mathrm{r}=0.84^{* * *} & \mathrm{r}=0.80^{* * *}\end{array}$

Yield

On average, all treatments gave a $42 \%$ higher yield in 1986 than in 1985 (Table 5). 
Table 5. The effect of different fertilization practices on the carrot yield.

\begin{tabular}{|c|c|c|c|c|}
\hline \multirow{2}{*}{\multicolumn{2}{|c|}{ Treatment }} & \multicolumn{2}{|c|}{$\begin{array}{l}\text { Yields and standard errors } \\
\text { tons/ha }\end{array}$} & \multirow{2}{*}{$\begin{array}{l}\text { Average } \\
\text { yield } \\
\text { tons/ha }\end{array}$} \\
\hline & & 1985 & 1986 & \\
\hline No & $\begin{array}{l}\text { fertilization } \\
\text { No irrigation } \\
\text { Irrigation }\end{array}$ & $\begin{array}{l}36.4 \pm 3.1 \\
32.0 \pm 3.0\end{array}$ & $\begin{array}{l}47.6 \pm 1.5 \\
45.8 \pm 5.4\end{array}$ & $\begin{array}{l}42.0 \\
38.9\end{array}$ \\
\hline NPK & $\begin{array}{l}\text { placement } \\
\text { No irrigation } \\
\text { Irrigation }\end{array}$ & $\begin{array}{l}37.7 \pm 2.7 \\
38.6 \pm 1.5\end{array}$ & $\begin{array}{l}50.6 \pm 2.4 \\
56.6 \pm 3.4\end{array}$ & $\begin{array}{l}44.2 \\
47.6\end{array}$ \\
\hline NPK & $\begin{array}{l}\text { broadcast } \\
\text { No irrigation } \\
\text { Irrigation }\end{array}$ & $\begin{array}{l}37.1 \pm 2.9 \\
25.9 \pm 2.6\end{array}$ & $\begin{array}{l}48.2 \pm 1.8 \\
48.2 \pm 4.8\end{array}$ & $\begin{array}{l}42.7 \\
37.1\end{array}$ \\
\hline NPK & $\begin{array}{l}\text { fertirrigation } \\
\text { No basic } \\
1 / 2 \text { NPK basic }\end{array}$ & $\begin{array}{l}35.1 \pm 5.9 \\
36.0 \pm 2.1\end{array}$ & $\begin{array}{l}52.1 \pm 3.7 \\
55.0 \pm 1.6\end{array}$ & $\begin{array}{l}43.6 \\
45.5\end{array}$ \\
\hline PK & $\begin{array}{l}\text { placement } \\
3 \mathrm{~N} \text { fertirrigation } \\
4 \mathrm{~N} \text { fertirrigation }\end{array}$ & $\begin{array}{l}39.8 \pm 2.0 \\
37.7 \pm 1.8\end{array}$ & $\begin{array}{l}48.4 \pm 6.5 \\
52.6 \pm 2.2\end{array}$ & $\begin{array}{l}44.1 \\
45.2\end{array}$ \\
\hline Avera & age yield & $35.6 \pm 1$ & $50.5 \pm 1.1$ & 43.1 \\
\hline
\end{tabular}

Contrast analysis revealed that placement fertilization produced higher yields than broadcast fertilization $\left(\mathrm{p}=0.009^{* *}\right)$. The yields were higher also when phosphorus and potassium were applied by placement fertilization compared to the treatments where $\mathrm{P}$ and $\mathrm{K}$ were not applied by placement method $\left(\mathrm{p}=0.03^{*}\right)$.

The split application did not affect the yield when compared to single application.

Of the individual fertilization practices, the best yield was obtained by irrigated placement fertilization, followed by NPK fertirrigation with NPK basic fertilization and PK placement with $4 \mathrm{~N}$ fertirrigations. NPK fertirrigation without basic fertilization gave moderate yields in each year. Broadcast fertilization proved to be the poorest method of fertilization, the yields being similar to those obtained with unfertilized treatments.

In a factorial experiment, irrigation decreased the yield in 1985 . The average yield for irrigated treatments was $32.2 \mathrm{t} / \mathrm{ha}$; for non-irrigated treatments it was $37.1 \mathrm{t} / \mathrm{ha}$ $\left(\mathrm{p}=0.03^{*}\right)$. In 1986, irrigation increased the yields. The yield of irrigated treatments averaged $50.2 \mathrm{t} /$ ha and of non-irrigated treatments $48.8 \mathrm{t} / \mathrm{ha}(\mathrm{p}=0.06)$. Placement fertilization yielded $38.2 \mathrm{t} / \mathrm{ha}$ and broadcast fertilization $31.5 \mathrm{t} / \mathrm{ha}(\mathrm{p}=0.06)$ in 1985 , in 198653.6 $\mathrm{t} / \mathrm{ha}$ and $48.2 \mathrm{t} / \mathrm{ha}(\mathrm{p}=0.10)$, respectively.

\section{Root/shoot ratio}

The root/shoot ratio increased and the differences between treatments increased with advancing growing season (Fig. 4).

\section{Dry matter content, shoots}

Fertilization did not affect the dry matter content as compared to unfertilized treatments. On the first, second and third sampling dates, the mean dry matter contents of shoots were $12.1 \%$ (range $11.7-12.6 \%$ ), $11.4 \%$ (range $11.0-12.0 \%$ ) and $14.0 \%$ (range $13.7-14.4 \%)$, respectively. On the first sampling date the dry matter content was higher for broadcast fertilization than for placement fertilization $\left(\mathrm{p}=0.009^{* *}\right)$. The value was also higher when $P$ and $K$ were not placement fertilized compared to $\mathrm{P}$ and $\mathrm{K}$ placement $\left(\mathrm{P}=0.009^{* *}\right)$. On the second and third sampling dates there were no statistical differences between fertilization practices. 

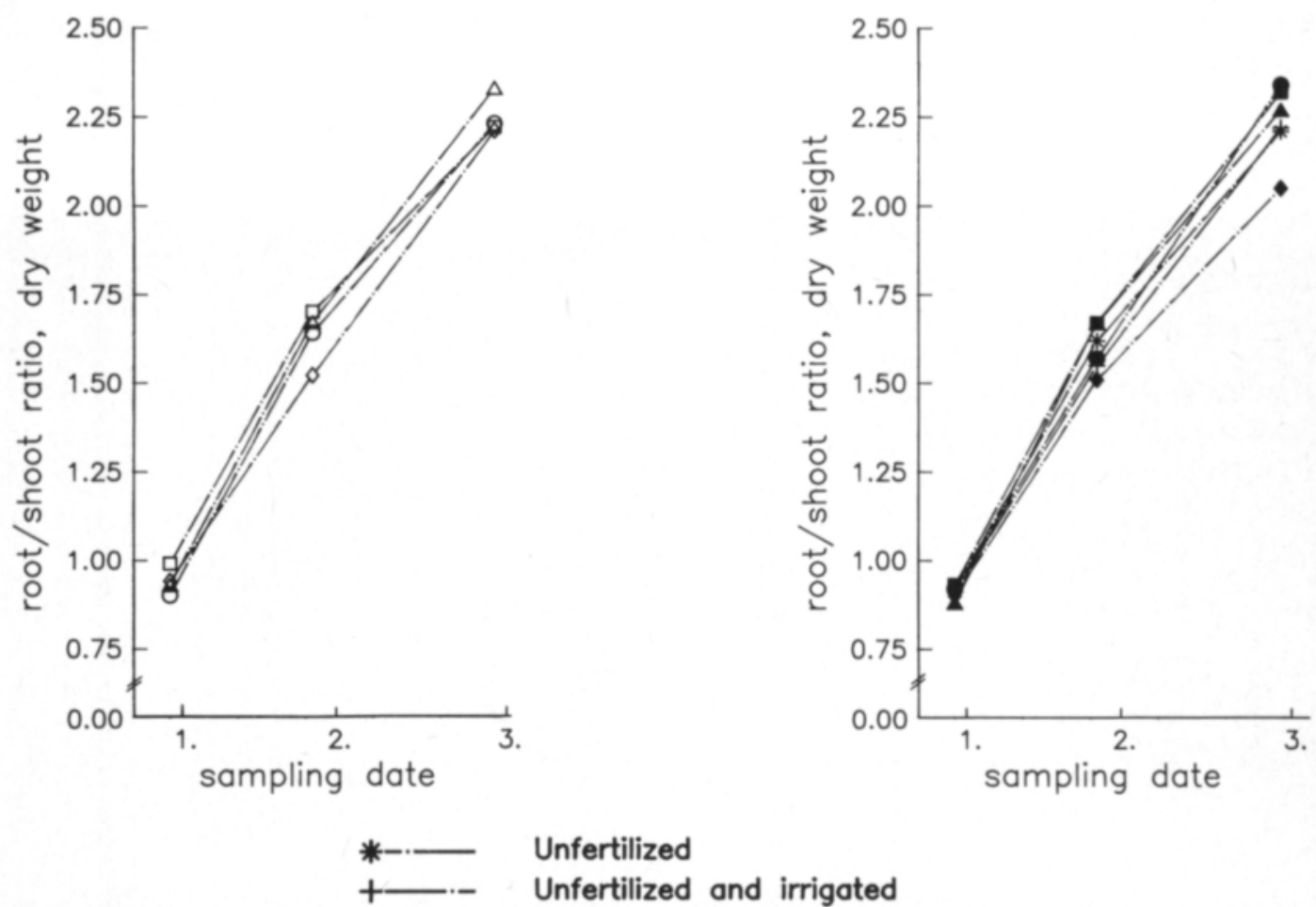

Unfertilized

Unfertilized and irrigated

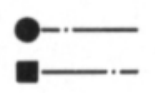

Placement fertilized

Placement fertilized and irrigated

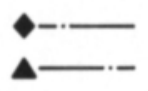

Broadcast fertilized

Broadcast fertilized and irrigated

$\Delta--\quad$ NPK fertirrigations, no basic

$\diamond-$ NPK fertirrigations, $1 / 2$ basic

O-- PK placement with $3 \mathrm{~N}$ fertirrigations

口-- $\quad$ PK placement with $4 \mathrm{~N}$ fertirrigations

Fig. 4. The effect of different fertilization practices on the development of the root/shoot ratio.

Dry matter content, roots

The dry matter content was lower in the roots than in the shoots. On the first sampling date, the mean root dry matter content was $9.1 \%$ (range $9.0-9.3 \%$ ), on the second sampling date $9.4 \%$ (range $9.1-9.6 \%$ ). On the second sampling date the dry matter content of roots was higher when basic and additional fertilization was used as compared to fertirrigation $\left(\mathrm{p}=0.006^{* *}\right)$. The dry matter content was also higher when $\mathrm{P}$ and $\mathrm{K}$ were applied by placement fertilization when compared to treatments where $\mathrm{P}$ and $\mathrm{K}$ were not placement fertilized $(\mathrm{p}=0.02 *)$. At harvest, the mean dry matter content was $10 \%$ (range $9.8-10.2 \%$ ). The dry matter content in roots was higher with the PK basic with $\mathrm{N}$ fertirrigations method than with the NPK fertirrigations treatments $\left(\mathrm{p}=0.03^{*}\right)$.

The content was also higher when basic and additional fertilization was used as compared to fertirrigation $\left(\mathrm{p}=0.05^{*}\right)$. 
There was a highly significant difference between the two years $\left(\mathrm{p}=0.000^{* * *}\right)$ as to root dry matter content. The mean values were $9.5 \%$ and $10.5 \%$ in 1985 and in 1986, respectively. When treatments P0-P5 were studied as a factorial experiment neither the fertilization method nor irrigation affected the dry matter content of carrot roots.

\section{Organically cultivated carrots}

The fresh and dry weights of shoots and roots are shown in Fig. 1. In the two organically cultivated fields, the yields were $46.2 \pm$ 1.4 and $41.4 \pm 2.7 \mathrm{t} / \mathrm{ha}$, respectively. The dry matter content of carrot shoots were $11.3 \%$ and $10.3 \%$ on first sampling date, at the second sampling date $11.8 \%$ and $9.6 \%$, respectively. At harvest, the shoot dry matter content was not determined. The root dry matter contents on three sampling dates were 9.4 and $9.1 \%, 7.1$ and $7.6 \%$ and 10.5 and $9.6 \%$, the root/shoot ratios on fresh weight basis were 2.7 and $1.8,3.3$ and 2.7 and 4.8 and 3.4 in the two organically cultivated fields respectively.

To make it easier to see the differences between the organically cultivated carrots and the carrots in the fertilizer experiment (the fertilized treatments), the mean values at harvest 1986 are listed side by side as follows:

$\begin{array}{lcc} & \begin{array}{c}\text { Organically } \\ \text { cultivated }\end{array} & \begin{array}{c}\text { Fertilization } \\ \text { experiment } \\ 1986\end{array} \\ & & 667 \\ \text { Shoot fresh weight g/20 carrots } & 424 & 85.8 \\ \text { Shoot dry weight g/20 carrots } & -^{*} & 2175 \\ \text { Root fresh weight g/20 carrots } & 1716 & 227.5 \\ \text { Root dry weight g/ } 20 \text { carrots } & 173.6 & 41.2 \\ \text { Yield kg/16 row meters } & 35.0 & 12.9 \\ \text { Shoot dry matter content \% } & -* & 10.5 \\ \text { Root dry matter content \% } & 10.1 & 3.3 \\ \text { Root/shoot ratio (fresh } & & \\ \text { weight basis) } & 4.1 & \\ \text { * Not determined } & & \end{array}$

The yield of organically cultivated carrots was somewhat smaller than the average yield for fertilized carrots grown in the fertilization experiment. There was no appreciable difference between root dry matter content but the root/shoot ratio was higher in organically grown carrots than in those grown in the fertilization experiment.

\section{Soil analysis}

The dissimilar effects of different fertilization practices on the soil nutrient concentrations can be verified by soil analysis (Fig. 5).

During germination the highest $\mathrm{NO}_{3}-\mathrm{N}$ concentrations $(\sim 25 \mathrm{mg} / \mathrm{l})$ were observed naturally in plots where all nutrients were given in single application before sowing (Fig. 5). In 1985 the $\mathrm{NO}_{3}-\mathrm{N}$ concentrations were $40-$ $50 \mathrm{mg} / 1$ during the first 50 days, and they decreased sharply thereafter in all fertilization treatments, except for placement fertilization, where the values ranged $50-90 \mathrm{mg} / 1$ during the first 50 days. In 1986 the highest $\mathrm{NO}_{3}-\mathrm{N}$ concentrations were observed in broadcast fertilization 30 days after sowing. In organically cultivated fields, the $\mathrm{NO}_{3}-\mathrm{N}$ concentration was $15 \mathrm{mg} / \mathrm{l}$ before sowing, increased to $25-$ $40 \mathrm{mg} / \mathrm{l}$ during the first 40 days and decreased thereafter.

In $1985,20-45 \mathrm{mg} / \mathrm{l}$ of $\mathrm{NH}_{4}-\mathrm{N}$ was detected in unfertilized and single-application treatments. In 1986, in split application treatments as well as in single-application treatments, the $\mathrm{NH}_{4}-\mathrm{N}$ concentration was $<10$ $\mathrm{mg} / \mathrm{l}$. In organically cultivated soils the values ranged $0-25 \mathrm{mg} / \mathrm{l}$.

The phosphorus concentrations were similar in all soil samples in the fertilization experiment. In organic cultivation the soils had a higher P content (Fig. 5).

The potassium content in unfertilized treatments decreased from $110 \mathrm{mg} / 1$ to $50 \mathrm{mg} / \mathrm{l}$ during the growing season (Fig. 5). Fertilization increased the $\mathrm{K}$ level in soils. In treatments where $\mathrm{K}$ was applied by placement fertilization potassium behaved similarily. During the first 40 days, the $\mathrm{K}$ values ranged $110-$ $150 \mathrm{mg} / \mathrm{l}$, then dropped to $\sim 100 \mathrm{mg} / \mathrm{l}$, and were $60-80 \mathrm{mg} / \mathrm{l}$ at harvest. In broadcast fertilization, the $\mathrm{K}$ levels were highest during the first 40 days, being $150-160 \mathrm{mg} / \mathrm{l}$; it decreased thereafter and was $70-80 \mathrm{mg} / \mathrm{l}$ at harvest. The potassium content in the fertirriga- 
tion treatment ranged $100-160 \mathrm{mg} / \mathrm{l}$. The $\mathrm{K}$ contents in organically cultivated fields were $90 \mathrm{mg} / \mathrm{l}$ and $200 \mathrm{mg} / \mathrm{l}$ seven days after sowing, increased thereafter at both locations, reached their maximum values $150 \mathrm{mg} / \mathrm{l}$ and $360 \mathrm{mg} / \mathrm{l}$ 40 days after sowing and finally decreased to the original values.

The calcium and magnesium values are not shown in Fig. 5 because they were very similar in all treatments. The $\mathrm{Ca}$ concentrations ranged from 800 to $1,600 \mathrm{mg} / \mathrm{l}$ in 1985 and from 1,900 to 3,000 in 1986 as a result of liming. In one of the organically cultivated fields, the Ca concentration was $800-1,100$ $\mathrm{mg} / \mathrm{l}$ and in the other $2,500-3,000 \mathrm{mg} / \mathrm{l}$. The magnesium concentrations ranged 30 $170 \mathrm{mg} / \mathrm{l}$ in the fertilization experiment, and in organically cultivated soils the $\mathrm{Mg}$ values were $100-170 \mathrm{mg} / \mathrm{l}$ and $290-360 \mathrm{mg} / \mathrm{l}$.

The $\mathrm{pH}$ was different in 1985 and in 1986 because of liming during the winter 1985/ 1986. The $\mathrm{pH}$ tended first to fall and then to rise during the growing season (Fig. 5).

The electrical conductivity (EC) during the first 30 days when carrots germinate and emerge was higher in single-application treatments than in split application treatments. In 1985 the treatments where $\mathrm{P}$ and $\mathrm{K}$ were applied by placement fertilization, the EC was higher than in other treatments. In 1986 the broadcast fertilization treatments had especially high EC, 20 days after sowing. The ECs of organically cultivated soils were of the same magnitude as in soils of the fertilization experiment.

\section{Discussion}

Carrot is one of the most important vegetables grown and stored in Finland. The growth of carrot is influenced by genotype, environment and growing techniques. In the present study, cv. Nantes Duke Notabene 370 was used. This variety is most commonly grown for the food industry in Finland.

The root and shoot dry weights were positively correlated on all sampling dates of both years $\left(r \geqq 0.77^{* * *}\right)$; big foliage produced high root yield. A similar result has been reported by Dragland (1978). Carrot shoots reached their maximum weight by three months whereas the roots grew slowly during the first two months, but growth increased considerably during the third and fourth months. Big photosynthetizing apparatus seemed provide plenty of photosynthates for the growing root.

\section{Placement fertilization}

The average carrot yield in Southern Finland is 23 tons/ha (range 18-28 tons/ha), and 30-36 tons/ha on contract farms (YLÄTALO 1982). The most common fertilization practice is broadcast fertilization. According to the present study, development of the fertilization practises could increase the carrot yield. The placement of granular NPK fertilizer increased the yield considerably as compared to broadcast fertilization of granular NPK fertilizer. The yield was also increased by the placement of $\mathrm{P}$ and $\mathrm{K}$ as compared to treatments where $\mathrm{P}$ and $\mathrm{K}$ were not applied by placement method.

EKEBERG (1986) also studied the effects of placement and broadcast fertilization on carrot, and found that placement fertilization increased carrot yield by $2 \%$ and $12 \%$ in the dry years of 1981 and 1982, respectively, but it did not affect the yield in the rainy year of 1980. In broadcast fertilization, the fertilizer granules remain in the top $0-5 \mathrm{~cm}$ of the soil (KAILA \& HÄNNINEN 1961), which dries quickly, and the granules thus do not dissolve in dry periods. In placement fertilization, the fertilizer granules are placed under the soil surface at a depth of $8-15 \mathrm{~cm}$, where moisture conditions remain optimal for granules to dissolve. In rainy years the granules dissolve also in the top soil layer. This may explain why EKEBERG (1986) did not get differences between placement and broadcast fertilization in the rainy year of 1980 .

ESALA \& LARPES (1986 a) have reported placement fertilization to increase barley and spring wheat yields, particularly at low fer- 
tilizer levels. The placement application increases the effiency of the fertilizer. In the present study, the difference in carrot yields between placement and broadcast practices would probably have been even bigger if a lower nutrient level had been used. The nutrient level used in the present experiment was chosen according to the practice in Finnish carrot production. It would be worth while to study the lowest effective fertilizer levels of placement method that would achieve yields similar to those of the inefficient broadcast method. From the ecological point of view, too, this would be an interesting topic. Nitrogen in particular is a nutrient which is easily leached by rain or irrigation (WATTS 1975).

\section{Fertirrigation}

Hergert (1977) reported that although all nutrients may be applied in the irrigation water, there are some limitations as to those that probably should not be applied, because of effectiveness. He claims that the nutrients which are not absorbed by the soil and which have a tendency to move with soil water are the ones best suited for sprinkler application. Thereby nitrogen, sulfur, and probably some of the chelated micronutrients are suited for application in irrigation water.

Nutrients such as $\mathrm{Mg}, \mathrm{Ca}, \mathrm{K}, \mathrm{P}$ and inorganic forms of micronutrient cations may be soluble in the irrigation water. Because of soil reactions, however, they tend to accumulate in the top inch or two of the soil surface. These nutrients would not be distributed throughout the root zone to be taken up by the roots of the growing crop (HERGERT 1977). On the contrary, storage organ of the carrot is formed of a tap root and hypocotyl, with lateral roots arising in both of them (EsAU 1940). This means that carrots have lateral roots along the soil profile, which can probably take up nutrients also from the top layer if the soil moisture content is optimal. But because the top layer is often dry, this may hinder the nutrient uptake of fertirrigated nutrients as well as broadcast nutrients.
Work by WATTS (1975) with sprinkler application of nitrogen solutions on sandy soils has shown greater efficiency of use from sprinkler-applied nitrogen than preplant broadcast nitrogen. In that study, the nitrogen losses increased as the nitrogen rate increased regardless of the application method. Much of the loss was due to leaching. Losses from the sprinkler-applied nitrogen (split) were lower than from the broadcast-applied nitrogen.

In the present study, no difference could be shown in yields between one application and split application. Future studies should investigate the effects with a lower fertilization level.

\section{Weather conditions}

There was wide variation in yields between the years. In 1986, the yields were significantly higher $\left(\mathrm{p}=0.000^{* * *}\right)$ than in 1985. BisHoP et al. (1973) has reported a wide range in carrot yields for different years at the same location as well as for different locations in the same year. VUORINEN \& TAKALA (1987) have reported $64 \%$ lower yields between 1980 and 1982 and, on average, $60 \mathrm{~kg} \mathrm{~N} / \mathrm{ha}$ gave the highest yield, but in 1980, $120 \mathrm{~kg} \mathrm{~N} / \mathrm{ha}$ gave the biggest yield. Also Nilsson (1979) has reported differences $(25 \%)$ in yields between years, whereas the amount of fertilizer was found to have no effect on carrot yields. In the present study the amounts of fertilizer used were higher in 1985 than in 1986. At least the higher $\mathrm{N}$ amount in 1985 did not affect on the yield levels, because the treatment PK placement with $4 \mathrm{~N}$ fertirrigations had very high nitrogen amounts in both years (155 kg N/ha in 1985 and $200 \mathrm{~kg} \mathrm{~N} / \mathrm{ha}$ in 1986), and in both years this treatment gave equally good yields as did the PK placement with $3 \mathrm{~N}$ fertirrigations. The surplus nitrogen did not lower the yield in either year.

\section{Irrigation}

Irrigation decreased the yields in 1985 and increased them in 1986, although the total 
precipitation was greater in 1986 than in 1985 . The high precipitation rate in June, 1985 should be noted. In that year heavy rains came two days after the first irrigation, at the time when seedlings began to emerge. The heavy rain caused a crust to form on the soil surface, and the crust hindered the emergence of seedlings and prevented gas exchange in the soil. The soil was fine sand which contained $15-30 \%$ clay, enough to form a crust. In both years the sowing could take place only very late. In 1985 the first irrigation and fertirrigation was done too early with respect to the sowing date. It would have been better to give the first fertirrigation only after plant growth had made a good start. Also the number of sunshine hours in June and July, 1985 was lower than in 1986, and retarded early development. In 1986, the first irrigation and fertirrigation was done not until at the end of June, which was favourable. Dragland (1978) has reported that an early drought period from the two true leaf stage onwards resulted in higher carrot root yield.

\section{Dry matter content}

In the present study, the mean dry matter content in roots was $10 \%$ at harvest. The difference in the dry matter content of roots was bigger between years than between fertilization practices. Similar results have also been reported by other researchers (DRAGLAND 1978, Aura 1985, VuORINEn \& TAKala 1987). These researchers found that increasing amounts of $\mathrm{N}$ did not affect the dry matter content in carrot roots. Aura (1985) and VUORINEN \& TAKALA (1987) also found that irrigation did not affect the dry matter content, but Dragland (1978) reported that a drought period before harvesting increased the dry matter content. In NiLsson's (1979) study there was no difference between the dry matter content of carrot roots with normal or half the normal NPK fertilizer levels. EKEBERG (1986) reported that placement fertilization decreased the dry matter content in carrot roots as compared to broadcast fertilization on peaty soil. Nor did an increased $\mathrm{N}$ amount decrease the dry matter content. In the present study, no difference was found between placement and broadcast fertilization, but the PK placement with $3 \mathrm{~N}$ fertirrigations had a higher dry matter content than the NPK fertirrigations treatments.

In the present study the dry matter content was, on average, somewhat lower than in the other experiments. The ranges were as follows: $9.0-10.2 \%$ (present study); 9.2$13.5 \%$ (Dragland 1978); 11.4-12.0\% (NILSSON 1979); 11.0-12.6 \% (Aura 1985); 10.6-11.2 \% (EKEBERG 1986); and 9.8$12.4 \%$ (Vuorinen \& TaKala 1987). The reason for the slightly lower mean dry matter content may be climatic or genetic. In both years September was rainy, and according to Dragland (1978), a dry period before harvest increases the dry matter content in carrot roots. BAJAJ et al. (1980) studied various chemical constituents of 23 carrot varieties grown in the same conditions. They found a $42 \%$ difference in the dry matter content of carrot varieties (range 7.9-11.2\%). DraGLAND (1978) and EKEBERG (1986) grew cv. Tip Top Red Core. Nilsson (1979) and AurA (1985) grew cv. Nantes Fancy Notabene, and VuOrinen \& TAKAla (1987) grew cv. Nantes Notabene 20.

\section{Root/shoot ratio}

The highest root/shoot ratios were found in fertilization practices which also had high yields. These were the irrigated placement fertilization and the $\mathrm{PK}$ placement with $4 \mathrm{~N}$ fertirrigations. The development of root/ shoot ratios in these treatments was 1.0$1.8-2.4$ and $1.0-1.7-2.3$ on the basis of dry weight on the first, second and third sampling dates, respectively. The trend was that the higher the yield, the bigger was the root/shoot ratio, with two exceptions, which were the PK placement with $3 \mathrm{~N}$ fertirrigations and irrigated broadcast fertilization.

A high yield was obtained by the PK placement with $3 \mathrm{~N}$ fertirrigations. This treatment 
favoured shoot growth. The treatment had the highest root and shoot dry weights, but the root/shoot ratio was only $0.9-1.5-2.0$, which means that dry weights of shoots were particularly high. The irrigated broadcast treatment had a high root/shoot ratio and a high root and shoot dry weight, yet the yield was low in both years. The reason for this inconsistency remained uncertain.

\section{Organically cultivated carrots}

The organically cultivated location one had low nutrient levels in the soil, with the except of $\mathrm{P}, \mathrm{Mn}$ and $\mathrm{Zn}$. Location 2 had high nutrient levels in soils, except for S. The nutrient amounts given by fertilization with compost were much higher than those in the fertilization experiment. The most distrikt difference between composts was the amount of water-soluble nitrogen. Despite the huge nutrient amounts, the fresh and dry weights of 20 carrots (Fig. 1) remained below the average value for 1986 in the fertilization experiment. The organically cultivated carrots were sown earlier than those of the fertilization experiment, and the root and shoot fresh and dry weights had already reached high levels on the first sampling dates. Location one got $113 \mathrm{~kg} / \mathrm{ha}$ water-soluble nitrogen, while location two only $47 \mathrm{~kg} / \mathrm{ha}$ watersoluble nitrogen. This is probably the reason for the lower yield at location two. There was no difference in the root dry matter content between the organically cultivated carrots and the fertilized carrots of the fertilization experiment.

The root/shoot ratio had to be calculated on the basis of fresh weight, because the shoot dry matter contents at harvest were not determined. The root/shoot ratio was higher for the organically grown carrots than was the average value for the fertilized carrots in the fertilization experiment.

According to these experiments, high carrot yields were obtained when the total biomass production was high. The big photosynthesizing foliage did produce plenty of photosynthates for the roots. It proved to be possible to increase the carrot yields by developing the fertilization practices. Placement fertilization increased the yields as compared to broadcast fertilization. The placement of $\mathrm{P}$ and $\mathrm{K}$ increased the yields, as compared to treatments where $\mathrm{P}$ and $\mathrm{K}$ were not applied by placement method. The split application did not affect the yield when compared to one application. Fertilization did not affect the dry matter content as compared to unfertilized treatments.

Acknowledgement. I am indebted and grateful to Ms. Oili Uusitalo for excellent technical assistance. I am grateful to Professor E. Kaukovirta, Professor A-L. Varis and M. Niemi, Lic. Phil., for their valuable comments on the manuscript. I also thank V-M. Taavitsainen, Lic. Phil., for advice in the statistical analysis and Mrs. A-M. Korhonen for the typing. I am grateful to the Academy of Finland and Kemira Oy for financial support.

\section{References}

AURA, E. 1967. Effect of the placement of fertilizer on the development of spring wheat. J. Sci. Agric. Soc. Finl. 39, 3: 148-155.

- 1985. Avomaan vihannesten veden ja typen tarve. Maatalouden tutkimuskeskus. Tiedote 7: 1-61.

BajaJ, K.L., Kaur, G. \& SukhiJa, B.S. 1980. Chemical composition and some plant characteristics in relation to quality of some promising cultivars of carrot (Daucus carota L.). Qual. Plant Plant Foods Hum. Nutr. 30: 97-107.
Berger, K.C. \& Truog, E. 1944. Boron tests and determination for soils and plants. Soil Sci. 57: 25-36.

Bishop, R.F., Chipman, E.W. \& Mac Eachern, C.R. 1973. Effect of nitrogen, phosphorus and potassium on yield and nutrient levels in carrots grown on sphagnum peat and mineral soils. Comm. Soil. Sci. PI. Anal. 4, 6: 455-474.

Bremner, J.M., Bundy, L-G. \& Agarwal, A.S. 1968. Use of a selective ion electrode for determination of nitrate in soil. Anal. Lett. 1: 837-844. 
Dragland, S. 1978. Nitrogen- og vassbehov hos gulrot. Forskn. Förs. Landbr. 29, 2: 139-159.

EKEBERG, E. 1986. Radgjödsling på myr. Forskn. Förs. Landbr. 37: 23-28.

Esala, M. \& LARPES, G. 1986 a. Effect of the placement technique and amount of fertilizer on spring wheat and barley grown on clay soils. I. Effect on grain yield. Ann. Agric. Fenn. 25: 159-167.

- \& LARPes, G. 1986 b. II. Effect on the quality and mineral contents of grain yield. Ann. Agric. Fenn. 25: $169-175$.

Esau, K. 1940. Developmental anatomy of the fleshy storage organ of Daucus carota. Hilgardia 13: 175225.

Hergert, G.W. 1977. Sprinkler application of fertilizer nutrients. Fert. Solutions 21, 2: 14-20.

Hole, C.C., Barnes, A., Thomas, T.H., Scott, P.A. \& Rankin, W.E. 1983. Dry matter distribution between the shoot and storage root of carrot (Daucus carota L.). Ann. Bot. 51: 175-187.

KAILA, A. \& ELonen, P. 1970. Influence of irrigation and placement of nitrogen fertilizers on the uptake of nitrogen by spring wheat. J. Sci. Agric. Soc. Finl. 42: $123-130$.

- \& HAnninen, P. 1961. Fertilizer nitrogen in soil. J. Sci. Agric. Soc. Finl. 33: 167-184.

Lakanen, E. \& Ervio, R. 1971. A comparison of eight extractants for determination of plant available micronutrients in soils. Acta Agric. Fenn. 123: 223-232.
NıLsson, T. 1979. Avkastning, lagringsförmåga, kvalitet och kemisk sammansăttning hos morot, vitkál och purjo vid konventionell och organisk gödsling. Inst. Trädg. Vet. Rapp. 7: 3-52.

Salonen, M., Tähtinen, H., Taimio, A., Kerannen, T., BARKoff, E. \& JoKINEN, R. 1965. Rikkipitoisten ja rikittömien moniravinteisten lannoitteiden käyttőarvoa selvitteleviă tutkimuksia. Summary: Comparative studies on the effect of sulphur-containing and sulphurfree multi-nutrient fertilizers. Ann. Agric. Fenn. 4: 155-177.

Steel, R.G.D. \& Torrie, J.H. 1980. Principles and procedures of statistics. A biometrical approach. 633 p. 2nd Ed. Tokyo.

TANAKA, A. 1980. Source and sink relationship in crop production. Food Fert. Techn. Center Techn. Bull. 52: $1-18$.

Vuorinen, J. \& MÁкıтıE, O. 1955. The method of soil testing in use in Finland. Agrogeol. Publ. 63: 1-44.

Vuorinen, M. \& TAKala, M. 1987. Porkkanan ja punajuurikkaan sadetus, typpilannoitus ja kalkitus poutivalla hiekkamaalla. Maatalouden tutkimuskeskus. Tiedote 10: 1-30.

W ATTS, D.G. 1975. A soil-water-nitrogen-plant model for irrigated corn on coarse textured soils. Ph. D. Dissertation. Utah State University.

Ylätalo, M. 1982. Avomaan vihannestuotanto. Sitra B 72: $1-150$.

\section{SELOSTUS}

\section{Lannoitusmenetelmien vaikutus porkkanan juurien ja naattien kuivapainoon, satoon, kuiva-ainepitoisuuteen ja juuri/naatti -suhteeseen}

\author{
Aino-Maija Evers \\ Kemira Oy, Espoon tutkimuskeskus, \\ Louteisrinne 2, 02270 Espoo
}

Eri lannoitusmenetelmien vaikutusta porkkanan 'Nantes Duke Notabene 370' juurien ja naattien kuivapainoon, satoon, kuiva-ainepitoisuuteen ja juuri/naatti -suhteeseen tutkittiin kenttäkokeina Kotkaniemen koetilalla Vihdissä 1985 ja 1986. Sijoitus- ja pintalannoitusta (ilman kastelua ja kastelun kera), NPK kastelulannoitusta, NPK kastelulannoitusta, jossa puolet ravinteista annettiin sijoittaen kevaaallă sekä koejäsentä, jossa $\mathrm{P}$ ja $\mathrm{K}$ annettiin sijoittaen keväällä ja $\mathrm{N}$ kastelulannoituksena kasvukaudella tutkittiin. Kokeessa verrattiin myös ravinteiden kertale- vitystä jaksotettuun ravinteiden antoon. Maan ravinnetilaa seurattiin maa-analyysein. Porkkanoiden juuri- ja naattinăytteet kerăttiin kolme kertaa kasvukauden aikana. Tulokset analysoitiin kontrastianalyysillä ja osa tuloksista varianssianalyysillä faktorikokeena.

Porkkanan naattien ja juurien kuivapainot korreloivat positiivisesti kaikkina näytteenottoaikoina molempina vuosina $\left(r \geqq 0.77^{* * *}\right)$. Suuri yhteyttãvă lehdistoo tuotti suuren juurisadon. Sijoituslannoitus lisăsi satoa verrattuna pintalannoitukseen $\left(\mathrm{p}=0.009^{* *}\right)$. Sato oli suurempi 
koejäsenissă, joissa P ja K oli sijoitettu verrattuna koejäseniin, joissa P:tä ja K:ta ei ollut annettu sijoituslannoituksena $\left(p=0.03^{*}\right)$. Sadossa ei ollut eroa annettiinpa ravinteet yhdellä kerralla tai jaksottaen.

Sadonkorjuuvaiheessa lannoitus ei vaikuttanut porkkanan juurien kuiva-ainepitoisuuteen verrattuna lannoittamattomiin koejäseniin. Kuiva-ainepitoisuuden erot oli- vat suuremmat eri vuosien vălillä ( $\left.\mathrm{p}=0.000^{* * *}\right)$ kuin lannoitustapojen välillä $\left(\mathrm{p}=0.05^{*}\right)$. Kuiva-ainepitoisuus oli suurempi koejäsenissä, joissa $\mathrm{P}$ ja $\mathrm{K}$ annettiin sijoituslannoituksena ja $\mathrm{N}$ kastelulannoituksena kuin koejäsenessä, jossa kaikki ravinteet annettiin NPK-kastelulannoituksena. 